\title{
29 \\ GRAVITATIONAL PULL OF AUTHORITARIAN CHINA IN SOUTH ASIA?
}

\author{
Johan Lagerkvist
}

A strong and worldwide wave of autocratization has gained much scholarly attention in recent decades (Diamond and Plattner 2002, Lührmann and Lindberg 2019). In many parts of the world, liberal democracies have become less liberal, while authoritarian regimes have become more entrenched. For a long time, researchers related international economic linkages between the United States and other countries to openness to influence of American political norms, such as competitive elections, rule of law, human rights - and in turn, to democratization (Levitsky and Way 2010). The rise of the People's Republic of China (PRC), and other wealthy autocracies, as new economic power houses, however, has raised questions about the influence of authoritarian norms as a consequence of new economic partnerships and political engagements (Gat 2007). Since the early 2000s international linkages and norms also include non-Western alternatives - particularly China's authoritarian developmental model.

Against the backdrop of an emerging cold war between the United States and China, many countries in all world regions are finding themselves under increasing pressure to choose sides, or find ways to cleverly cooperate with both, between a liberal-democratic and free-market capitalist US camp, or a Leninist-authoritarian and state capitalist Chinese camp. We may thus find countries to oscillate between professed political ideals and economic needs and realities. In a climate of cold war rhetoric, American policymakers and analysts argue that China's government seeks to replace the US-led liberal and democratic world order with its own authoritarian model. In a speech in 2020, former US Secretary of State Mike Pompeo stated that "General Secretary Xi Jinping is a true believer in a bankrupt totalitarian ideology. It's this ideology, it's this ideology that informs his decades-long desire for global hegemony of Chinese communism" (Pompeo 2020). An already bankrupt ideology should not scare anyone, and there is no belief in China that "Chinese communism" will prevail globally, as Chinese analysts have noted the declining attraction of the PRC and its president Xi Jinping among populations around the world. Nevertheless, Pompeo's focus on ideology is important as it's a rallying cry for conservative Republicans and "China hawks" in the US Congress. Ideology can also be diffused in other ways than crude propaganda. More nuanced is the argument of Aaron Friedberg, who in Foreign Affairs argued that "Abandoning its past reluctance to be seen as an ideological challenge to the West, it now openly offers its mix of authoritarian politics and quasi-market economics as a model for nations that want to, in Xi's words 'speed up their development while preserving their independence"' (2020). The surfacing reality of constructed binary ideological opposites 
and actually existing strategic security competition presents a challenge for small and mediumsized powers in all world regions. It is also troublesome for China, where analysts long have warned about turning geo-economic and geopolitical competition with the United States into an ideological battle, since this would mobilize diverse US interests against China. Arguably the Trump presidency managed to do just that, by labelling telecom firm Huawei as an agent of the Chinese party-state. For less affluent countries in Asia, the geographic proximity to rising China presents a particular set of opportunities and challenges. Regimes, ruling political parties, civil society, and opposition groups in neighbouring countries are affected, due to intensified political and economic relations with China under the framework of the Belt and Road Initiative (BRI), which will connect countries across the vast Eurasian landmass. China, no doubt, pursues geopolitical and geo-economical strategies on regional and global levels, but is there an ideological component to these strategies - perhaps even autocracy promotion - akin to the logic of democracy promotion of the United States and its allies? This chapter seeks to tentatively answer this question by reviewing some of the theoretical and empirical literature on the subject, with a particular eye on developments in South Asia under the BRI-framework. $\mathrm{Xi}$ started to communicate his ideas of the BRI and his loose global plan for a "community of common destiny" immediately when taking office in March 2013, and he has since outlined the vision to global audiences at the United Nations headquarters in New York and at the World Economic Forum in Davos.

\section{Autocracy diffusion and promotion}

The worldwide turn towards authoritarianism has been conceptualized and studied as autocratization (Lührmann and Lindberg 2019; Skaaning 2020) and "democratic back-sliding", (Bermeo 2016). Most studies focus on domestic transformation and formal institutional setups, but some scholars have theorized international linkages of authoritarian rule as autocracy diffusion (Ambrosio 2010), autocracy promotion (Burnell 2010; Bader 2015), and authoritarian policy transfer/learning (Hall and Ambrosio 2017). The potential of creation and spread of nonWestern norms has been scrutinized in international relations scholarship (Acharya 2004), and empirically studied in connection with Russian, Brazilian, and Chinese proposals to multilateral institutions. This literature suggests that cross-national ties in political, economic, and social dimensions contribute not only to the process of democratic diffusion and democratization of authoritarian regimes (Levitsky and Way 2010), but also to the autocratic diffusion and survival of incumbent autocratic leaders. International linkages may reduce the political space for democratic openings (Cameron and Orenstein 2012) but also protect and embolden autocratic elites (Vanderhill 2013). Autocratization oftentimes takes place as a gradual process, while keeping the facade of democratic institutions, such as elections for the legislative and executive branches (Cianetti and Hanley 2021). It is manifest in the practice of state power, using new and innovative techniques of repression (Morgenbesser 2020). Instead of banning NGOs, the ruling elites create government-organized NGOs (GONGOs) to generate the impression that civil society actors support government and muddle the political discourse by inserting moral relativity. Instead of imprisonment of political dissidents, for example, they raise the costs of being dissident by filing defamation lawsuits. Moreover, increasing linkages between autocratic regimes do not only diffuse innovative autocratic techniques internationally, they also provide the material basis for autocratic regimes - through increasing mutual reliance in the policy areas of trade, migration, and diplomacy (Tansey et al. 2017). The spread of ideas from major authoritarian powers, on how to govern, is an important phenomenon since autocratization within a country seldom takes place in a context of insularity. One country's democratic regression, or 
autocratic consolidation, can be facilitated by other autocratic regimes. Such processes can be intended or unintended, directly or indirectly, actively or passively. In an important intervention, Oisin Tansey proposed that the concept of autocracy promotion should be used carefully to avoid conceptual overstretch. It is applicable when, and only when, there is "clear intent on the part of an external actor to bolster autocracy as a form of political regime as well as an underlying motivation that rests in significant part on an ideological commitment to autocracy itself" (2016: 142). This strict definition is useful as it disaggregates intentions, targets, and motives from the overburdened concept. He also leaves out the effects-side from the definition, as effects are hard to ascertain and lead to unsubstantiated claims, as in the literature on democracy promotion (Finkel et al. 2007). Policies without intention to spur autocratization can still have such effects, and policies with such clear intent can be ineffective. However, his key assertion about ideological commitment to a particular model of political regime as a "twentieth century phenomenon" of the fascist and communist past has echoes of Fukuyaman's "end of history". It neglects or underestimates the Chinese communist party's continuing adherence to the principles of Leninism, and pragmatic but firmly autocratic "Dengism" as is clear from former leader Deng Xiaoping's statements and speeches (Deng 2006). On the other end of the spectrum, as illustrated by remarks in the US foreign policy community there's overestimation and hyperbole regarding China's intent to export authoritarianism. China has certainly been active in denigrating liberal democracy, highlighting its failures, and preventing democracy promotion/diffusion in its regional neighbourhood (e.g. Hong Kong, Taiwan, South Korea). But there is little, if any, evidence of the PRC actively involved in autocracy promotion to other countries. An open question, however, is if "authoritarian learning/teaching" about China's developmental model and the central tenets of its mode of governance can be said to take place in bilateral and multilateral channels. These channels include preparation and negotiation of Chinese diplomatic proposals at the United Nations Human Rights Commission in Geneva, where China has forwarded "anti-universalist" human rights proposals in recent years (Richardson 2020), and suggestions to the International Telecommunications Union (ITU) that Western countries respect China's and other developing countries' "cyber sovereignty" and particularist conceptions of free speech (Segal 2020). But it can also take place on a bilateral basis. Thus, as a role model China can diffuse authoritarianism, but without having an explicit ideological content or intent, in line with Kneuer's and Demmelhuber's concept authoritarian gravity centre (2016), which lesser authoritarian states orbit around and learn from. For China it would be beneficial to see diffusion of its own norms and principles of governance to others. As Ambrosio has argued, authoritarian diffusion methods such as these serve to generally legitimate autocracy in the international system (2010: 377). Moreover, in concrete terms, the adoption of Chinese-made norms, technological standards and business practices could ease friction in multilateral and bilateral settings, serve to legitimate Chinese state capitalism, as well as increase economic opportunities for Chinese state-owned companies.

\section{Authoritarian policy transfer/learning from China}

Before Xi Jinping's ascent to power in the Chinese communist party, Yan Xuetong, a leading Chinese scholar of international relations, pondering China's increasing soft power, hoped that China would be able to "narrow the gap in these areas [sic!] within four to five years" (Yan and $\mathrm{Xu}$ 2008). Yet during the recent decade, and particularly after the failed containment of the Covid-19 virus in China, the attraction of the PRC among publics in the more affluent democracies has declined significantly (Silver et al. 2020). The advent of a strategically and diplomatically more assertive, and at times quite aggressive foreign policy is an obvious reason for 
this decline in public opinion worldwide. There is emerging scholarly consensus that the ascent to power of Xi Jinping has propelled a more assertive shift in Chinese foreign policy. In a time when Chinese efforts at soft power in the Global North are abandoned, there is a concerted push for advocating the successes of Beijing's developmental model in the Global South and at the United Nations (Liu 2018). Under the umbrella of the vision of Community of Common Destiny and the BRI, new forums of "South-South Cooperation" have also been created to better communicate China's developmental experience and policy successes (Peng 2017). Chinese state media, for example, has expanded globally and broadcast in many local languages. From around the world, journalists and educators, and GONGOs are invited to China to study the prerequisites of China's phenomenal economic growth. There are also new efforts at joint party-building exercises between the CCP and political parties in the Global South, as well as regular visits between parliaments and court systems. The Beijing-based Africanist He Wenping has argued that Africa is a "proving ground [sic!] for Beijing's community with a shared future doctrine" (2020: 40). Furthermore, she holds that: "African leaders are turning to Beijing for valuable lessons in not only traditional development issues like poverty reduction and economic growth but also government efficiency and ruling party building" (2020: 44). But not only African elites are impressed, as many citizens find China's developmental model attractive (Lekorwe 2016). The argument about party-building is in line with extant research, which argues that since Xi Jinping took office, the international department of the Chinese Communist Party has become more active, and is a "vehicle of authoritarian learning by sharing experiences of its modernization and authoritarian one-party regime" (Bader and Hackenesch 2019: 10). And as has been argued by Kneuer and Hemmelhuber, these kinds of "collaborative networks constitute the channels of communication (horizontal and vertical), which enhance the spread of ideas and institutional or policy innovations" (2016: 781). And Morgenbesser has likewise argued that "stransnational alliances between ruling parties are formal agreements to provide mutual support for the maintenance of autocratic rule", and that this "increasing cooperation between autocratic ruling parties around the world means opposition parties will suffer the consequences of innovation" (2020: 5). A case in point was the revelation that Chinese company Huawei's techniques of digital surveillance have aided governments to spy on opposition parties in African countries (Parkinson et al. 2019). This phenomenon warrants further study, as research by Bader showed that economic cooperation with China contributed to regime durability in those authoritarian countries that were party-based regimes (2015: 672). Political, economic, security and technological elites are arguably attracted to China's model of "technocratic developmentalism" with its focus on stability, order through digital surveillance techniques, and emerging standards and modes of data-driven algorithmic governance. More research focus on government-to-government authoritarian policy transfer/learning is needed as autocrats strengthen governance and party institutions through sharing experiences. The idea that authoritarian gravitation centres play "a role as an important pull factor for emulation, imitation or policy transfer" (Kneuer and Demmelhuber 2016: 777) - and influence institutional, policy, ideational, and administrative techniques in other countries - is gaining more importance.

\section{Diluting democracy and redefining human rights}

Over time China has moved from defence of the PRC's policies "with Chinese characteristics", to normative defence of states in the Global South and their right more generally to choose their own path of development, without interference of Western countries and their universalist teaching and preaching (Kinzelbach: 2012). With Xi Jinping's grand vision of a Community of 
common destiny for mankind, China has taken one more step. As elucidated in a key speech at the United Nations in 2017 (Hua 2017) and as outlined in a speech on a more active foreign policy at the 18th Party Congress, this vision showcases "Chinese solutions" to all the grave issues facing humanity, such as climate change and socioeconomic inequality. The PRC has since become more involved in authoritarian teaching of its developmental model and particularist values and norms. Thus, China has entered a new phase of more confidently transferring ideas of a specific Chinese model of development, and successfully made policy inroads in multilateral settings, such as the UN Human Rights Commission. I would argue that the fundamental tenets of this governance model consist of:

1) socio-political stability (including what in India is called "majoritarianism" and what some scholars have labelled "authoritarian peace" within a country)

2) subnational experimentation to enhance economic growth and social stability

3) promoting the right to choose developmental alternatives according to cultural context

4) non-interference in domestic sovereign politics

5) defence of particularism against what China's government frame as "so-called universal human rights".

Yet the overall modicum is still mostly defensive and related to China's core interests of sovereignty, territorial integrity, and non-interference. However, there is also a rising and troubling tendency in Western academia, especially among scholars trained at Chinese universities, to redefine the very meaning of democracy through describing China's autocracy as "vertical democracy" (Guo 2020). Similar academic tricks of moving goalposts are also used to overemphasize creativity and under-emphasize censorship in China's digital economy. It is probable that these efforts to reject (Western) universalism and instead offer "Chinese solutions" to global governance will increase in the post-pandemic phase, when score-cards over the failures of the largest Western democracies, the United States and the UK, are measured with China's health protection and sustained economic growth. It can be foreshadowed that in its vison of a "community of common destiny" China will advocate that collective safety and order and state sovereignty of states in the Global South must come before individual liberties.

In a world characterized by a declining United States, under conditions of mulitipolarity, China's normative arguments could propel the world into "ideational anarchy" where concepts of democratic human rights are diluted or even redefined. In the marketplace of ideologies and ideas, countries may freely choose developmental alternatives: liberal democracy or authoritarian "vertical democracy"; universal human rights or particularist rights that are culturally context-specific. On the one hand the results of China's governance have an impact by "speaking for themselves", on the other these objective results can be amplified by tailored information to target countries in the Global South.

\section{China in South Asia}

The existence of autocracy promotion by China in Southeast Asia has been investigated and refuted by Bader (2014) and Noesselt (2021). China's role in this regard as a force promoting autocratization has been studied by Vanderhill in Central Asia (2013) and Brautigam in Africa (2009) with similar results. On South Asian countries there is limited research on China's authoritarian influence. Discussion of China's relations with countries in this region mostly concerns China's economic and strategic influence and does not concern ideological components 
or Beijing as a prop for incumbent autocrats. According to Kneuer and Hemmelhuber, an authoritarian gravity centre "constitutes a pull factor in the regional environment: as a country that has the kind of leverage to promote autocratic elements or a country that is an attractive model for countries in geopolitical proximity, as it provides policy solutions that are perceived as suitable" (2016: 780). Whether China is seen as an attractive model in South Asia depends on what national setting, and which social group, a person belongs to. Since the announcement in 2013 of the BRI, the presence of activities fuelled by Chinese capital investment is keenly felt in the region. The initiative amounts to the Chinese state's monumental undertaking to connect countries via physical, digital and financial infrastructure across the Eurasian landmass and through the "Indo-Pacific region" to East Africa.

Among the South Asian countries, only Pakistan is a long time "all-weather friend" of China. However, not even this country has proven easy to cooperate with under the BRIframework. For the success of the BRI, its flagship project the China-Pakistan Economic Corridor (CPEC) has been judged as crucial. However, there's been a heated debate in Pakistan and criticism of Chinese investments since 2017 (Dorsey 2019: 193). The foreign policy risks for Beijing and the vulnerabilities of rising China in connection with BRI (Cooley 2016), should not be underestimated as the tortuous progress of the CPEC has shown. Islamabad's arch-enemy India, on the other hand, has quite predictably remained suspicious of the BRI and China's long-term intentions. Partly because of Indian and American suspicion, Chinese analysts have also been prudent in their strategic assessments, not wishing through their writings to initiate a process that might shift the geopolitical and military balance in the Indian Ocean. Chinese caution is evident also in the limited military connections with other equally cautious small South Asian countries that avoid upsetting India's military (Samaranayake 2019: 8). It is one thing to provoke border skirmishes along the contested Sino-Indian border in the Himalayas, and quite another to patrol the sea around India with naval vessels and submarines. Instead, China has over the last decade sought to bolster good impressions through economic activities. Yet these attempts, and an ambition to increase Beijing's soft power, have been selfdefeating, especially in the case of its longstanding adversary India (Jain 2017). And according to an informant in Ghiasy's study on Indian perceptions of China's geopolitical strategy under the BRI: "China is using micro-steps to encroach on and make advancements in South Asia's security realm: first through diplomacy, then through the economy, and then into security. Over time, in the aggregate, these micro-steps become major strides" (2021: 273). Yet, policy transfer and authoritarian learning from China can take place outside the realm of security strategy. In India's move towards “majoritarianism” (Sahoo 2020), for example, and its exclusionary practices regarding Muslim and other non-Hindu minorities, the ideational pull of China as an "authoritarian gravitational centre" on countries where democratic regression is ongoing should not be ruled out. Whereas Western democracies have condemned China's treatment of its Muslim minorities in the Xinjiang region, many states in the Global South have abstained from such criticism. The reasons may vary, but autocrats or elites in ethnically diverse countries could ponder harsher minority policies to achieve political stability and economic development. In non-consolidated democracies such as Myanmar and Bangladesh, and in even more entrenched autocracies, such as Vietnam, leaders could follow the Chinese example of high-tech control in Xinjiang to enable a domestic "authoritarian peace". Jain notes that China's rise has afforded smaller nations in South Asia, such as Nepal, Bangladesh, Myanmar, Sri Lanka, and the Maldives, opportunities to swing out of India's sphere of interest. Aid and investments from China under BRI, as well as wishes to unhook from Indian tutelage, have propelled smaller South Asian countries to edge closer to China, to further their bargaining power vis-à-vis India (Ghiasy 2021: 272). 
Yet, these economic and political motivations are offset by increasing Chinese assertiveness in the South China Sea and along the disputed border with India. It is especially the 99-year lease of Sri Lanka's Hambantota deep-sea port that has received attention in South Asian countries. Many observers have accused Beijing of conducting "debt trap diplomacy". The policies of China's state-owned policy banks do deserve scrutiny. Yet, as Sri Lanka's debt to China is only 5.9 per cent of all its foreign debt (Samaranayake 2019), such terminology lends itself to exaggeration. Nonetheless it is argued that concerns about the Hambantota affair in the region after 2017 "have not been eased by Chinese insistence that the investments are purely commercial in nature [and have] seriously damaged China's BRI soft power drive in South Asia" (Garlick 2018: 530).

China exerts significant influence in Dhaka due to its long-term support of Bangladesh's military. With Xi Jinping's visit to Bangladesh in 2016, this influence was expected to grow, as huge Chinese investments under the BRI agenda were promised. It was seen as evidence for China's expanded foothold in South Asian countries (Kumar 2019: 150). Yet, most of the projects and billions Xi earmarked for Bangladesh, worth USD 24 billion, have not materialized, as only three projects totalling USD 1.2 billion have been initiated. The overall impression is that initial grandiose ambitions and promises of the BRI have not materialized on the ground. Domestic backlashes against China's economic influence, as in Sri Lanka and Pakistan, as well as the Covid-19 pandemic, can explain some of the delays.

Uncertainty surrounding Beijing's long-term and far from transparent strategy should also be factored into the equation. Clouded in secrecy and contradictory as its diplomacy oscillates between assertiveness and prudence, Chinese foreign policy is notoriously hard to interpret. According to $\mathrm{Pu}$ Xiaoyu, China's diplomatic Janus face should be understood as China's leaders signalling to both domestic and international audiences, but also as a fundamental uncertainty about its changing role in world politics (Pu 2019). Several important empirical studies from around the world have refuted the Chinese party-state's direct involvement in autocracy promotion. However, more subtle diffusion of autocratic practices could be an outcome of China's growing influence as a role model. It can come as a by-product of economic leverage such as investment, trade, foreign aid, loans, technological standards, statecraft, and role-modelling in educational programmes and state visits. And as noted recently by Bader and Hackenesh (2019), the limited evidence of Chinese autocracy promotion is mainly manifest from the period before the 18th Communist Party Congress in 2017. At this important congress, Xi Jinping announced a strategic shift to actively communicate China's developmental experience. This has to date taken form, more as authoritarian learning than actual autocracy promotion. And as discussed above, China's vigorous defence of its authoritarian polity and attacks on universal human rights and re-defining of democracy are contributing to a global trend of ideational anarchy.

One avenue of future research in this field of communicating China's developmental experience concerns political relations, especially ties between the international department of the Chinese Communist party and political parties in South Asia. Chinese aid in party-to-party dialogues is underway with political parties in Pakistan and Bangladesh (Dawn Newspaper 2019). Notwithstanding nationalist resistance in South Asian countries against China's advance of geopolitical and geo-economical interests under the BRI, its mode of governance may still inspire, especially compared to recent perceptions of failings of Western democracies. This phenomenon especially warrants studies in countries such as Bangladesh, with a social memory of single-party rule, as described in the chapter by Ali Riaz in this volume. 


\section{Concluding remarks}

Despite the transformation to a more assertive foreign policy under Xi Jinping, China's strategy remains relatively reactive, notwithstanding more vehement responses to statements about human rights abuses in the Xinjiang region. China is sensitive to arguments of not being a responsible stakeholder in the liberal world order and criticism of its human rights record. At the same time, China also responds to stimuli from states in the Global South to shoulder more responsibility to lead, and take political, not just geo-economic, initiatives. If governments, in Asia and Africa for example, express views that China act more decisively on the international stage, China may be nudged to act, and also should act as a role model, for states in the Global South. Thus, it is logical that Chinese foreign policy shift gears. China usually protest against democracy promotion by the United States and other liberal democracies, but do not actively have a programme to frustrate democracy promotion on the ground (Bader 2014, 2015; Noesselt 2021). Incremental changes have led to a more assertive China under Xi Jinping. Under Xi's rule China has initiated a process to move away from Deng Xiaoping's foreign policy tenet to "lie low and bide time" for ideas to "do some things" internationally (Yan 2008). As yet, however, this is not an ideologically assertive China, as US analysts and policymakers increasingly claim. One needs to distinguish between China's security-related, geo-economic, and political interests and influences. Nonetheless, the fundamental pillars underpinning Chinese technocratic and autocratic practices may come to inspire and exert attraction among autocrats elsewhere. Even in the absence of clear autocratic promotion, as no ideological "push factors" exist, it's still feasible that China's developmental technocracy and tenets on hierarchy, political stability, and minority policies may resonate with other countries' elites, civil servants, and technical experts. As a "pull factor" it could thus contribute to domestic processes of autocratization. The outcome of such processes is likely to differ across the spectrum of authoritarian settings, fragile democracies, and consolidated democracies. Autocrats in firm autocratic settings are emboldened by China, in less-than-consolidated democracies autocratic forces in society are energized. Autocrat-minded leaders even in Chinesesceptical democracies such as India and Japan could perhaps be swayed by China-made norms and principles. Thus, the issue of a gravitational pull of authoritarian China is likely to grow in importance on the research agenda of autocratization in South Asia and beyond. However, autocratization can also come as a by-product of Chinese push-factors unrelated to its own governance model. If China would abandon strategic caution in the Indo-Pacific as it has done in the South China Sea, Premier Modi in India could as a response to Chinese assertiveness argue that civil liberties be curtailed to unify the country to withstand China. In light of persistent border skirmishes between India and China in recent years, and Modi's repeated attempts to reap electoral benefits by pointing to the military threat from Pakistan, such a scenario is not a foregone conclusion (Singh 2021).

Empirical research shows that China is not intentionally and actively exporting its particular political system overseas. Yet there are central tenets and principles of China's state-capitalist governance model that are taught to countries in the Global South, and forcefully defended in multilateral forums and argued as superior to Western democracy in diplomatic rhetoric and state-propaganda. These tenets are: socio-political stability, subnational experimentation to enhance economic growth and social stability, promotion of the right to developmental choice according to cultural context, non-interference in domestic sovereign politics, defence of particularism against what China's government frame as "so-called universal human rights". It would be negligent to believe that arguments about the logic and superiority of these tenets will fall on deaf ears, especially since China's concrete economic and social health scorecard in the post-pandemic Covid-19 phase 
speaks louder than words. According to Tansey's strict criteria and definition, these arguments hardly belong to active and intentional "autocracy promotion". Nevertheless, China's rhetoric in bilateral, regional, and multilateral settings and negotiations carries subtle ideological weight and erodes belief in the liberal and democratic principles of governance. Over time the gravitational pull of authoritarian China may propel autocratization, without it being the intended goal of autocracy promotion. Future empirical studies should, as argued by Kneuer and Hemmelhuber, explore "which mode of influence used by the authoritarian gravity centre (active intentional export or unintentional diffusion) is more effective in reality". Recent trends of authoritarian learning from, and teaching of, China's developmental model indicate that gravitational pull of China and intentional diffusion of governance practices are becoming real-world phenomena. This may not be overtly exporting world revolution from a Stalinist Soviet Union, which according to Oisin Tansey, amounts to real autocracy promotion having an explicit ideological commitment. Yet China’s twenty-first century "authoritarian learning” and policy transfers may prove to be more effective precisely because they are so covert.

\section{Bibliography}

Acharya, Amitav. (2004) 'How Ideas Spread: Whose Norms Matter? Norm Localization and Institutional Change in Asian Regionalism,' International Organisation, 58(2), pp. 239-275.

Akhter, Majed. (2018) 'Geopolitics of the Belt and Road: Space, State, and Capital in China and Pakistan' in Logistical Asia: The Labor of Making a World Region, Neilson, B., Rossiter, N., Samaddar, R., (eds.) (Singapore: Palgrave Macmillan, pp. 221-241).

Ambrosio, Thomas. (2010) 'Constructing a Framework of Authoritarian Diffusion: Concepts, Dynamics, and Future Research,' International Studies Perspectives, 11, pp. 375-392.

Ambrosio, Thomas. (2012) 'The Rise of the 'China Model' and 'Beijing Consensus': Evidence of Authoritarian Diffusion?’ Contemporary Politics 18(4), pp. 381-399.

Bader, Julia. (2014) China's Foreign Relations and Autocratic Survival (Abingdon: Routledge).

Bader, Julia. (2015a) 'Propping up Dictators? Economic Cooperation from China and its Impact on Authoritarian Persistence in Party and Non-party Regimes,' European Journal of Political Research, 54(4), pp. 655-672.

Bader, Julia. (2015b) 'China, Autocratic Patron? An Empirical Investigation of China as a Factor in Autocratic Survival,' International Studies Quarterly, 59(1), pp. 23-33.

Bader, Julia and Hackenesh, Christine. (2019) 'China: Same, Same, but Different?' The Annals of Comparative Democratization, 17(2), pp. 8-11.

BBC. (2021) 'Sikkim: Chinese and Indian troops 'in new border clash', www.bbc.com/news/world-asia55793112 (Accessed 7 March 2021).

Bermeo, Nancy. (2016) 'On Democratic Backsliding,' Journal of Democracy, 12(1), pp. 5-19.

Brautigam, Deborah, (2009). The Dragon's Gift: The Real Story of China in Africa (Oxford: Oxford University Press).

Bunce, Valerie, and Wolchik, Sharon. (2009) 'A Regional Tradition: The Diffusion of the Democratic Change under Communism and Postcommunism,' pp. 30-58, in Democracy and Authoritarianism in the Postcommunist World, Valerie Bunce, Michael McFaul, and Kathryn Stoner-Weiss (eds.) (Cambridge: Cambridge University Press).

Burnell, Peter. (2010) 'Is there a New Autocracy Promotion,' FRIDE Working Paper 96.

Cameron, David R. and Orenstein, Mitchell A. (2012) 'Post-Soviet Authoritarianism: The Influence of Russia in Its 'Near Abroad,' Post-Soviet Affairs, 28(1) pp. 1-44.

Cianetti, Licia, and Hanley, Sean. (2021) 'The End of the Backsliding Paradigm,' Journal of Democracy, 32(1), pp. 66-80.

Cooley, Alexander. (2016) The Emerging Political Economy of OBOR: The Challenges of Promoting Connectivity in Central Asia and Beyond (Washington DC: CSIS).

Dawn Newspaper. (2019) 'Chinese Communist Party, PTI Discuss Cooperation', 28 November. Available at: www.dawn.com/news/1519224/chinese-communist-party-pti-discuss-cooperation (Accessed 7 March 2021).

Deng, Xiaoping. (2006) Selected Works by Deng Xiaoping, Vol.1 (Beijing: People's University Press). 


\section{Gravitational pull of authoritarian China?}

Diamond, Larry and Plattner, Marc (eds.). (2002) Democracy after Communism (Baltimore: Johns Hopkins University Press).

Dorsey, James M. (2019) China and the Middle East: Venturing into the Maelstrom (Cham, Switzerland: Palgrave Macmillan).

Finkel, Steven E., Perez Linan, Anibal S., and Seligson, Mitchell A. (2007) 'The Effects of U.S.Foreign Assistance on Democracy Building, 1990-2003,' World Politics, 59(3), pp. 404-439.

Friedberg, Aaron. (2020) 'The Way to Push Back Against Beijing,' Foreign Affairs, October/November.

Garlick, Jeremy. (2018) 'Deconstructing the China-Pakistan Economic Corridor: Pipe Dreams Versus Geopolitical Realities,' Journal of Contemporary China, 27(112), pp. 519-533.

Gat, Azar. (2007) 'The Return of Authoritarian Great Powers', Foreign Affairs, July/August.

Ghiasy, Richard. (2021) 'The Belt and Road Initiative in South Asia: Regional Impact and the Evolution of Perceptions and Policy Responses,' pp. 265-290, in Global Perspectives on China's Belt and Road Initiative: Asserting Agency through Regional Connectivity, Schneider, Florian (ed.) (Amsterdam: Amsterdam University Press).

Guo, Baogang. (2020) 'A Partocracy with Chinese Characteristics: Governance System Reform under Xi Jinping,' Journal of Contemporary China, 29(126), pp. 809-823.

Hall, Stephen G.F. and Ambrosio, Thomas. (2017) 'Authoritarian Learning: A Conceptual Overview, East European Politics, 33(2), pp. 143-161.

He, Wenping. (2020) 'A Community with a Shared Future: Beijing's Vision of China-Africa Relations,' China Quarterly of International Strategic Studies, 6(1), pp. 38-51.

Hua Xia. (2017) 'Backgrounder: 10 key quotes from Xi's speech at UN Office at Geneva,' www.xinhuanet.com/english/2017-01/19/c_135994782.htm (Accessed 21 March 2021).

Jain, B.M. (2017) China's Soft Power Diplomacy in South Asia: Myth or Reality (Lanham: Lexington Books).

Kapur, Ashok. (2015) 'Aftermath of the 1962 War,' www.indiandefencereview.com/spotlights/aftermathof-the-1962-war/, 13 November (Accessed 7 March 2021).

Kenderdine, Tristan and Han, Ling. (2018) 'International Capacity Cooperation - Financing China's Export of Industrial Overcapacity, Global Policy, 9(1), pp. 41-52.

Kinzelbach, Katrin. (2012) 'Will China's Rise Lead to a New Normative Order? An Analysis of China's Statements on Human Rights at the United Nations (2000-2010), Netherlands Quarterly of Human Rights, 30(13), pp. 298-332.

Kumar, Sanjeev. (2019) 'China’s South Asia Policy in the New Era', India Quarterly, 75(2), pp. 137-154.

Kneuer, Marianne and Demmelhuber, Thomas. (2016) 'Gravity Centres of Authoritarian Rule: A Conceptual Approach,' Democratization, 23(5), pp. 775-796.

Lekorwe, Mogopodi et al. (2016) 'China's Growing Presence in Africa Wins Largely Positive Popular Reviews,' Afrobarometer Dispatch, pp. 1-31.

Levitsky, Stephen and Way, Lucian A. 2010 Competitive Authoritarianism: Hybrid Regimes after the Cold War (Cambridge: Cambridge University Press).

Liu,Huawen. (2018). 'China'snewcontributiontohumanrights,'ChinaDaily, http://global.chinadaily.com.cn/ a/201803/29/WS5abc2a4da3105cdcf6514f0b.html (Accessed 18 March 2021).

Lührmann, Anna and Lindberg, Staffan. (2019) 'A Third Wave of Autocratization Is Here: What Is New About It?’ Democratization, 26(7), pp. 1095-1113.

Morgenbesser, Lee. (2020) 'The Menu of Autocratic Innovation,' Democratization, https: //doi.org/ 10.1080/13510347.2020.1746275.

Noesselt, Nele. (2021) 'China's New Regional Responsiveness: Passive Agency and Counter-Agency in Processes of Democratic Transitions in Asia,' Democratization 28(1), pp. 219-236.

Parkinson, Joe, Bariyo, Nicholas and Chin, Josh. (2019) 'Huawei Technicians Helped African Governments Spy on Political Opponents,' The Wall Street Journal. www.wsj.com/articles/huawei-technicians-helpedafrican-governments-spy-on-political-opponents-11565793017?mod=breakingnews (Accessed 7 March 2021).

Peng, Ying (2017) 'Full text of Beijing Declaration adopted by the First South-South Human Rights Forum,' Xinhua, www.xinhuanet.com//english/2017-12/08/c_136811775.htm (Accessed 18 March 2021).

Pompeo, Mike. (2020) 'Secretary Michael R. Pompeo Remarks at the Richard Nixon Presidential Library and Museum: Communist China and the free world's future,' https: //sv.usembassy.gov/secretarymichael-r-pompeo-remarks-at-the-richard-nixon-presidential-library-and-museum-communistchina-and-the-free-worlds-future/ (Accessed 16 February 2021). 


\section{Johan Lagerkvist}

Pu, Xiaoyu (2019) Rebranding China: Contested Status Signaling in the Changing Global Order (Stanford: Stanford University Press).

Richardson, Sophie. (2020) 'China's Influence on the Global Human Rights System: Assessing China's Growing Role in the World,' www.hrw.org/news/2020/09/14/chinas-influence-global-humanrights-system\# (Accessed 7 March 2021).

Silver, Laura, Devlin, Kat, and Huang, Christine C. (2020) 'Unfavorable Views of China Reach Historic Highs in Many Countries: Majorities say China has handled COVID-19 outbreak poorly,' www.pewresearch.org/global/2020/10/06/unfavorable-views-of-china-reach-historic-highs-inmany-countries/ (Accessed 7 March 2021).

Samaranayake, Nilanthi. (2019) 'China's Engagement with Smaller South Asian countries,' Special Report, United States Institute of Peace, No. 446, April.

Sahoo, Niranjan. (2020) 'Mounting Majoritarianism and Political Polarization in India', Carnegie Endowment for Peace, https: //carnegieendowment.org/2020/08/18/mounting-majoritarianism-andpolitical-polarization-in-india-pub-82434 (Accessed 7 March 2021).

Segal, Adam. (2020) 'China's Alternative Cyber Governance Regime,' Council on Foreign Relations, www.hrw.org/news/2020/09/14/chinas-influence-global-human-rights-system\# (Accessed 7 March 2021).

Singh, Sushant. (2021) 'Why China Is Winning Against India,' Foreign Policy, https: //foreignpolicy.com/ 2021/01/01/india-china-himalayas-ladakh-standoff/ (Accessed 7 March 2021).

Skaaning, Svend-Erik. 2020 'Waves of Autocratization and Democratization: A Critical Note on Conceptualization and Measurement,' Democratization, 27(8), pp. 1533-1542.

Tansey, Oisin (2016) 'The Problem with Autocracy Promotion,' Democratization, 23, 141-163.

Tansey, Oisin, Koehler, Kevin, and Schmotz, Alexander. (2017) 'Ties to the Rest: Autocratic Linkages and Regime Survival,' Comparative Political Studies 50, pp. 1221-1254.

Vanderhill, Rachel. (2013) Promoting Authoritarianism Abroad (Boulder: Lynne Rienner Publishers).

Widmalm, Sten. (2019) 'A most dangerous interaction effect in India,' https: //theasiadialogue.com/2019/ 10/24/a-most-dangerous-interaction-effect-in-india/ (Accessed 6 March 2021).

Yan, Xuetong and Xu, Jin. (2008) 'Sino-US. Comparisons of Soft Power', Contemporary International Relations, March/April, www.imir.tsinghua.edu.cn/publish/iis/7236/20120308004022054904369/ 2008-3Sino-U.S.ComparisonsofSoftPower.pdf (Accessed 7 March 2021). 